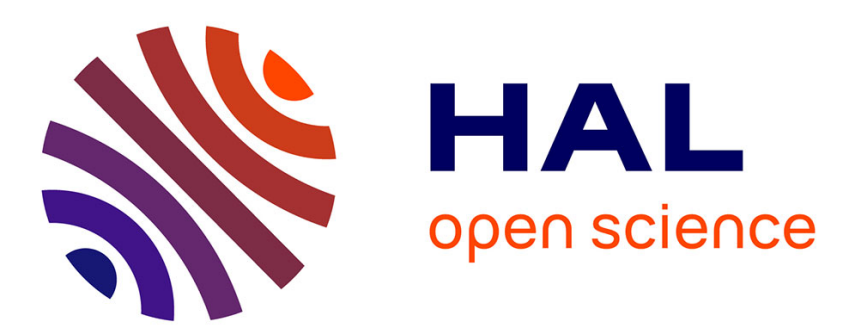

\title{
Knowledge-based approach for the 3D modeling of masonry structures
}

\author{
Kevin Jacquot, Tommy Messaoudi, Livio de Luca
}

\section{To cite this version:}

Kevin Jacquot, Tommy Messaoudi, Livio de Luca. Knowledge-based approach for the 3D modeling of masonry structures. Digital Heritage International Congress DH'15, Sep 2015, Grenade, Spain. 10.1109/DigitalHeritage.2015.7419487 . hal-02890045

\section{HAL Id: hal-02890045 \\ https://hal.science/hal-02890045}

Submitted on $10 \mathrm{Jul} 2020$

HAL is a multi-disciplinary open access archive for the deposit and dissemination of scientific research documents, whether they are published or not. The documents may come from teaching and research institutions in France or abroad, or from public or private research centers.
L'archive ouverte pluridisciplinaire $\mathbf{H A L}$, est destinée au dépôt et à la diffusion de documents scientifiques de niveau recherche, publiés ou non, émanant des établissements d'enseignement et de recherche français ou étrangers, des laboratoires publics ou privés. 


\section{Knowledge-based approach for the 3D modeling of masonry structures}

\author{
Kevin Jacquot \\ ENSA Nancy, MAP-CRAI \\ UMR MAP n ${ }^{\circ} 3495$, CNRS \\ Nancy, France \\ jacquot@map.cnrs.fr
}

\author{
Tommy Messaoudi, Livio de Luca \\ MAP-GAMSAU \\ UMR MAP n ${ }^{\circ} 3495$, CNRS \\ Marseille, France \\ \{first name.name\}@map.cnrs.fr
}

\begin{abstract}
In architectural heritage field, the control over metric data is fundamental. Indeed the interpretability of geometrical concepts, the criteria and methods to structure information are the first step for the analysis and simulation for the conservation of ancient buildings. The main barrier is to move from survey raw data to $3 D$ models that are understandable. To overcome this issue a knowledge-based approach is developed to carry out a reverse engineering for digitised masonry structures.
\end{abstract}

Index Terms-Architectural knowledge, 3D semantic model, masonry structure, data post-processing, reverse-engineering

\section{INTRODUCTION}

The Monumentum project aims at developing a software platform for the management of knowledge that enhances the comprehension and analysis of degradation phenomena affecting ancient buildings. Various disciplines are mobilized in order to define a prototype information processing workflow including spatial analysis of surfaces, geometric models of structures, heterogeneous documentary sources, etc. One of the issues of this project is related to $3 \mathrm{D}$ modeling and architectural strucuring based on digital surveys. 3D digitization techniques allow the creation of precise digital models of ancient buildings but whatever their accuracy or realism these models are not adapted to conservation analysis purposes. The specific objective of our task is to develop and experiment a process for the treatment of point clouds in order to create a computational model dedicated to mechanic behavior analysis. This article presents preliminary experiments to meet that objective. Following this introduction, the paper presents in part 2 a state of the art in reality-based semantic modeling applied to ancient architecture. Part 3 describes the method we are currently developing as well as the first experiments and results.

\section{STATE OF THE ART}

Many methods can be considered to model semantic contents from 3D raw data. The required level of detail, the geometric complexity of the studied object or the quality of raw data are several criteria that may be used to determine what is often called "Scan-to-BIM" process [1]. In many case, the aim is not so much the creation of building information models but rather the parametric (and in some case the semantic) modeling of existing buildings [2]. The creation of such models is only one side of the BIM approach as it aims at overcoming geometrical issues regarding data size, gaps and accuracy. Indeed, acquired 3D data have to be processed in order to create geometric models based on parametric entities models which are accurate mathematical models that replaced approximate meshed representations. For this purpose, new tools and functionalities have been introduced in existing architecture software to read point-cloud files. In many projects, Autodesk Revit is used to perform reality-based modeling [3]-[6]. Even if the software is originally intended for computed aided design, a number of initiatives were developed in the reverse engineering field. A first example is the GreenSpider project of TC Labs [4]. This plug-in of Revit allows the conversion of point clouds into input parameters for the natives tools of the software. However, the points that are imported into Revit are already segmented. In 2012, Autodesk Labs presented Point Cloud Feature Extraction for Autodesk Revit technology: a prototype of a reverse engineering tool integrated into Revit 2012 software. It provided datum, building and floor extraction but also automatic straight wall extraction for the creation of basic parametric Revit elements [6]. Parametric modeling is the keystone of reverse engineering approaches. Textual programming languages were already used to create parametric models for the $3 \mathrm{D}$ modeling of ancient buildings. However, they required a significant learning period before achieving the implementation of algorithms. Since 2007 and the release of new parametric software like Grasshopper, the algorithms can be achieved through visual programming language thus decreasing the back and forth switching between the geometric shape and the algorithms, which in turn may allow the designers to focus their attention on design. Previous experiments were accomplished with Grasshopper for the architectural features extraction such as regulating lines, which are used to control the proportion and placement of elements in other proportioning systems as well [7]. Notable experiments of modeling based on the use of regulating lines include the military architecture features modeling such as bastioned fortification [8] and civil architecture features such as classical orders [9], [10] or gothic windows tracery [11], [12].

\section{KNOWLEDGE-BASED MODELING: INITIAL EXPERIMENTS}

The Monumentum project relies on a domain ontology that is developed from several reference materials including dictionaries [13] or stereotomy treatises [14], [15] to identify masonry structure architectural components. The latter are essential to model the vocabulary (i.e. all the terms describing the components of the domain) and the grammar (i.e. all the design rules fixing the constraints between components) of 
masonry structures. Based on the ontology, a library of parametric models containing architectural objects is implemented in Grasshopper. The library is made of parametric arch curves which can be used in turn to create most of the vault types. Once the point clouds are imported in Grasshopper, they must be manually segmented into smaller samples. Each of them has to contain a single arch or vault intrados. These samples are then used as input parameters in an automatic process that instantiated every arch curves of the library. The point clouds are projected onto the instances according to the shortest distance. The sum of the distances between the original and the projected points allows the identification of the arch type but also to position and to have dimensions attributed to the parametric arch by using directly the point clouds characteristics. The depth of arches or vaults is also automatically retrieved which allow the sweep of arch curves along a trajectory, thus resulting on the creation of intrados.

\section{CONCLUSION AND FUTURES WORKS}

Monumentum aims at the creation of an information system dedicated to ancient building degradation monitoring based on semantic annotation of photographs [16]. For that purpose, several tools have to be developed and especially a domain ontology describing the knowledge related to degradation phenomena and architectural morphology. The ontology is also used for the creation of specific 3D models. In this paper, we presented the very first experiments on the automation of the modeling of architecture masonry structures based on 3D surveys. Preliminary results are promising (fig. 1). In the long term, the resulting semantic curves are intended to be used in Revit for the making of the $3 \mathrm{D}$ models of the whole masonry structure. For that purpose, we can rely on the software library as well as a dedicated library that will use the segmented arches as input parameters. The low level of detail of the resulting $3 \mathrm{D}$ models should have little impact on their use. They will be converted to meet the requirements for the next step of Monumentum project, which is static behavior analysis.

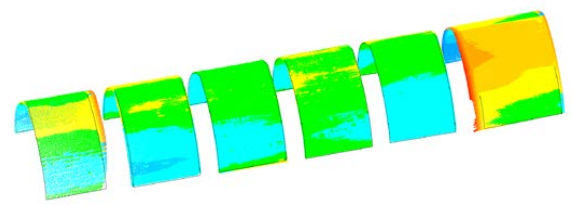

Fig. 1. Assessment of b-rep barrel vaults accuracy in Geomagic software. The average distance is $1 \mathrm{~cm}$ and the standard deviation is $12 \mathrm{~cm}$.

\section{COPYRIGHT FORMS}

You must submit the IEEE Electronic Copyright Form (ECF) as described in your author-kit message. THIS FORM MUST BE SUBMITTED IN ORDER TO PUBLISH YOUR PAPER.

\section{REFERENCES}

[1] R. Volk, J. Stengel, and F. Schultmann, "Building Information Modeling (BIM) for existing buildings - Literature review and future needs," Autom. Constr., vol. 38, pp. 109-127, Mar. 2014.

[2] C. Dore and M. Murphy, "Semi-Automatic Modelling of Building Facade with Shape Grammars Using Historic Building Information Modelling," 2013.

[3] R. Quattrini, E. S. Malinverni, P. Clini, R. Nespeca, and E. Orlietti, "From TLS to HBIM. High Quality SemanticallyAware 3D Modeling of Complex Architecture," ISPRS - Int Arch. Photogramm. Remote Sens. Spat. Inf. Sci., vol. XL-5/W4, pp. 367-374, Feb. 2015 .

[4] S. Garagnani and A. M. Manferdini, "Parametric Accuracy: Building Information Modeling Process Applied to the Cultural Heritage Preservation," in International Archives of the Photogrammetry, Remote Sensing and Spatial Information Sciences, Volume XL-5/W1, 2013, Trente, Italie, 2013, vol. XL5/W1, pp. 87-92.

[5] A. Bregianni, "BIM Development for Cultural Heritage Management," National Technical University of Athens School of Rural \& Surveying Engineering Lab of Photogrammetry et Politecnico di Milano School of Architecture B.E.S.T Department, Athènes, Grèce, Diploma Thesis, Jun. 2013.

[6] Autodesk Labs, Autodesk Labs: Point Cloud Feature Extraction for Revit - Arc Walls Extraction. 2012.

[7] F. D. K. Ching, Architecture: Form, Space, and Order, 3rd ed. John Wiley \& Sons, 2012.

[8] K. Jacquot, C. Chevrier, and G. Halin, "Reverse engineering of scale models using dataflow programming: Application to the fortification of plans-reliefs," in Digital Heritage International Congress (DigitalHeritage), 2013, 2013, vol. 1, pp. 63-69.

[9] C. Chevrier and J.-P. Perrin, "Generation of architectural parametric components: cultural heritage 3D modelling," in Joining Languages, Cultures and Visions: Proceedings of the 13th International CAAD Futures Conference, Montréal, Canada, 2009, pp. 105-118.

[10] L. De Luca, P. Veron, and M. Florenzano, "Reverse engineering of architectural buildings based on a hybrid modeling approach," Comput Graph, vol. 30, no. 2, pp. 160-176, Apr. 2006.

[11] S. Havemann and D. W. Fellner, "Generative Parametric Design of Gothic Window Tracery," in Proceedings of the Shape Modeling International, Genova, Italy, 2004

[12] J. Takayama, "Computer-generated Gothic Tracery with a Motif-oriented Approach," in Proceedings of IASDR 2013, Tokyo, Japan, 2013.

[13] J.-M. Pérouse de Montclos, Architecture: description et vocabulaire méthodiques. Paris: Éd. du Patrimoine, Centre des monuments nationaux, 2011

[14] J. Rondelet, Traité théorique et pratique de l'art de bâtir. Tome 2. A. Rondelet fils (Paris), 1830.

[15] J. Chaix, Traité de coupes des pierres. H. Chairgrasse fils (Paris), 1890.

[16] T. Messaoudi, A. Manuel, E. Gattet, L. De Luca, and P. Véron, "Laying the Foundations for an Information System Dedicated to Heritage Building Degradation Monitoring Based on the 2D/3D Semantic Annotation of Photographs," 2014 